\title{
Žák se zrakovým postižením jako klient školského poradenského zařízení
}

\section{Child with Visual Impairmet as a School Counseling Client}

Hana Ryšlavá, Technická univerzita v Liberci, Liberec

\begin{abstract}
Abstrakt
Příspěvek je orientován do oblasti školského poradenství pro žáky se speciálními vzdělávacími potřebami, konkrétně pak se zrakovým postižením. Na základě zkušeností ze speciálně pedagogické praxe poukazuje na to, jak se specifika dětí se zrakovým postižením promítají do poskytování poradenských služeb a následně také podpůrných opatření. Zamýšlí se nad proměnou klientely školského poradenství a jejími potřebami, s akcentem na nutnost multidisciplinárního př́stupu.
\end{abstract}

\section{Klíčová slova}

zrakové postižení, školské poradenství, multidisciplinární přístup

\section{Abstract}

The paper is focused on school counseling for pupils with special needs, specifically with visual impairment. Based on experiences from special pedagogical practice points out how the specifics of children with visual impairment are reflected in school counselling services and also in support measures. Considers the transformation of the school counselling clientele and its needs with an emphasis on the need for an multidisciplinary approach.

\section{Keywords}

visual impairmet, school counseling, multidisciplinary approach

\section{Úvod}

Školské poradenství má celou řadu úkolo̊, aktuálně platná legislativa jasně definuje, k čemu má směřovat. V rámci příspěvku nejprve vymezujeme dítě se zrakovým postižením a jeho potřeby, věnujeme se školskému poradenskému zařízení, které těmto dětem zpravidla poskytuje poradenské služby, a následně se zamýšlíme nad proměnou klientely a jejích potřeb. Poukazujeme na skutečnost, že prosperitu dítěte se zrakovým postižením ve školním prostředí je vhodné řešit v širších souvislostech, s využitím multidisciplinárního nebo lépe transdisciplinárního přístupu.

\section{Dítě se zrakovým postižením ve školském poradenském zařízení z pohledu aktuální legislativy a odborné literatury}

Hovoříme-li o dítěti se zrakovým postižením v kontextu školského poradenství, bylo by správné užívat spíše označení „žák“, se kterým operuje i aktuálně platná legislativa. Dovolíme si ovšem pracovat převážně s pojmem „dítě“, které lépe reflektuje zaměření na člověka a také připomíná, že speciální vzdělávací potřeby, které ve školském poradenství primárně řešíme, zdaleka nejsou vázány jen na školní prostředí, že jejich př́činy a důsledky mají daleko širší souvislosti.

Legislativně vycházíme ze tři základních dokumentů. Jedná se o zákon č. 561/2004 Sb. (tzv. Školský zákon), vyhlášku 27/2016 Sb., o vzdělávání žáků se speciálními potřebami a žáků nadaných, a vyhlášku 
72/2005 Sb., o poskytování poradenských služeb ve školách a školských poradenských zařízeních, všechny samozřejmě v aktuálním znění. V nich je sice jasně, ale jen poměrně stručně definováno, kdo je žákem se speciálními vzdělávacími potřebami - se zrakovým postižením, kdo, resp. co je školské poradenské zařízení, komu jsou jeho služby poskytovány, jaké jsou jeho standardní činnosti a jakou konkrétní podporu může žák se zrakovým postižením čerpat.

\section{Dítě se zrakovým postižením}

Školský zákon (par. 16 odst. 1) uvádí, že „dítětem, žákem a studentem se speciálními vzdělávacími potřebami se rozumí osoba, která k naplnění svých vzdělávacích možností nebo k uplatnění nebo užívání svých práv na rovnoprávném základě s ostatními potřebuje poskytnutí podpůrných opatření." Podpůrnými opatřeními se přitom rozumí „nezbytné úpravy ve vzdělávání a školských službách odpovídající zdravotnímu stavu, kulturnímu prostředí nebo jiným životním podmínkám dítěte, žáka nebo studenta." (ŠZ, par.16, odst.1). Konkrétní vymezení žáků se zrakovým postižením ale v tomto dokumentu nenalezneme.

Pro potřeby tohoto příspěvku je proto nezbytné také jasné vymezení jedince se zrakovým postižením. Za toho je z pohledu speciální pedagogiky považován každý, kdo i po optimální korekci má v běžném životě problémy se získáváním a zpracováváním informací zrakovou cestou (Valenta a kol. 2003). Lidé se zrakovým postižením se přitom z hlediska speciálně pedagogického dělí do čtyř základních kategorií, z nichž každá má z pohledu školské podpory jiná specifika a tedy i jiné nároky. První z těchto kategorií jjou lidé s nevidomostí. Jedná se o lidi s nejtěžším stupněm zrakového postižení, kteří mají minimální nebo žádné možnosti získávat informace zrakovou cestou. U nich pak v rámci všeobecné podpory pracujeme především na výuce čtení a psaní Braillova písma, výuce prostorové orientace a samostatného pohybu, výuce sebeobsluhy a práce se speciálními pomůckami. Všechny oblasti přitom prolíná rozvoj nižších i vyšších kompenzačních činitelů. Velmi blízko mají k této kategorii lidé se zbytky zraku. Úroveň jejich zrakového vnímání se nachází někde na pomezí mezi nevidomostí a slabozrakostí (viz níže), často je u nich přítomno progresivní oftalmologické onemocnění. Podpora proto musí být velmi flexibilní, reagující na momentální stav zraku, jež se může reálně pohybovat od pásma slabozrakosti až po nevidomost.

Lidé se slabozrakostí jsou kategorií velmi různorodou. Mají sice možnost využívat zrak, ale jejich zrakové vnímání je v různé míře omezeno, narušeno, deformováno. Jedná se o skupinu lidí, kteří jsou vysoce citliví k dodržování zrakové hygieny. Jejich podpora tedy spočívá mimo jiné v komplexní úpravě prostředí tak, aby požadavkům zrakové hygieny vyhovovalo (zvětšování, zvýrazňování vizuálních materiálo̊, vhodné osvětlení, vhodné pracovní místo), dále ve vhodném nastavení režimu práce (nepřetěžování, umožnění relaxace s ohledem na zvýšené nároky na koncentraci pozornosti apod.), či použííání speciálních pomůcek.

\section{Školské poradenské zařízení}

Školským poradenským zařízením se ve smyslu vyhlášky č. 72/2005 Sb., o poskytování poradenských služeb ve školách a školských poradenských zařízeních (ve znění aktuálních předpisů) rozumí pedagogicko-psychologická poradna (PPP) a speciálně pedagogické centrum (SPC). Pro potřeby tohoto příspěvku se dále budeme věnovat pouze SPC, protože právě to je zaměřeno (mimo jiné) na žáky se zrakovým postižením. Dle této vyhlášky (par. 6) má každé SPC, bez ohledu na klientelu, následující úkoly:

- zjištuje připravenost žáků se speciálními vzdělávacími potřebami na povinnou školní docházku;

- zjištujuje speciální vzdělávací potřeby žákůn, zpracovává podklady pro nastavení podpůrných opatření, pro přeřazení žáků do škol a tříd zřizovaných dle par. 16 odst. 9 SZ;

- zajišttuje speciálně pedagogickou péči a speciálně pedagogické vzdělávání pro žáky z běžných škol;

- vydává zprávu z vyšetření a doporučení ke vzdělávání za účelem stanovení podpůrných opatření;

- vydává zprávu a doporučení pro zařazení žáka do školy zřízené dle par. 16 odst. 9 ŠZ;

- poskytuje kariérové poradenství;

- vykonává speciálně pedagogickou a psychologickou diagnostiku a poskytuje poradenské služby se zaměřením na pomoc při řešení problémů ve vzdělávání, v psychickém a sociálním vývoji žáků;

- poskytuje pedagogickým pracovníkům a zákonným zástupcům poradenství ve věci vzdělávání;

- poskytuje metodickou podporu škole;

- poskytuje informační, konzultační, poradenskou a metodickou podporu zákonným zástupcům žáků. (vyhláška č. 72/2005 Sb.) 
V příloze č. 2 zmíněné vyhlášky jsou dále podrobněji rozpracovány společné činnosti všech SPC, přičemž jsou tyto činnosti rozděleny do tří oblastí - komplexní nebo zaměřená speciálně pedagogická nebo psychologická diagnostika, speciálně pedagogická a psychologická intervence a poradenská podpora, informační a metodická činnost, podpora a evidence. Pro SPC, které poskytuje služby žákům se zrakovým postižením, jsou pak jeho úkoly ve stejné příloze konkretizovány takto:

- individuální speciálně pedagogická a psychologická diagnostika pro účely stanovení podpůrných opatření a v případě potřeby i zpracovávání návrhů na vzdělávání žáka ve třídě zřízené pro žáky se zrakovým postižením;

- nácvik specifických činností,

- rozvoj zrakových funkcí, zraková stimulace;

- smyslová výchova;

- propedeutika čtení a psaní Braillova písma a zvětšeného černotisku;

- tyflografika, nácvik podpisu;

- zraková hygiena;

- rozvoj matematických představ, rozvoj estetického vnímání;

- nácvik orientace a samostatného pohybu, nácvik sebeobsluhy;

- poskytování informací o pomůckách zákonným zástupcům a pedagogickým pracovníkům;

- realizace sociálně rehabilitačních programů;

- zajištování odborných konzultací a metodické podpory pro zákonné zástupce a pedagogy;

- práce se speciálními učebnicemi a pomůckami. (vyhláška č. 72/2005, Sb., př́lloha č. 2)

\section{Podpora žáků se zrakovým postižením}

Legislativní vymezení a konkretizaci podpory pro žáky se zrakovým postižením nalezneme ve vyhlášce č. 27/2016 Sb., o vzdělávání žáků se speciálními vzdělávacími potřebami a žáků nadaných. V ní jsou v paragrafu 2 popsány stupně podpůnných opatření, a v dalších paragrafech jsou pak jednotlivá podpůrná opatření, tak, jak je známe z výčtu uvedeného ve Školském zákoně, rozpracována. Stanoveny jsou také náležitosti Zprávy z vyšetření a Doporučení ke vzdělávání. V přílohové části vyhlášky (4. Část B) je výčet podpory konkretizován s ohledem na potřeby žáka se zrakovým postižením, spolu s názvem (resp. typem) pomůcky je vždy uvedena také normovaná finanční náročnost.

Podpora žáků se zrakovým postižením ve smyslu podpůrných opatření je dále poměrně podrobně popsána v Katalogu podpůrných pro žáky s potřebou podpory z důvodu zrakového postižení a oslabení zrakového vnímání (Janková a kol. 2015). V něm jsou v rámci jednotlivých karet podpůrných opatření prezentovány oblasti podpory, vždy s návodem, jak je aplikovat do praxe a krátkou ilustrativní kazuistikou. V souladu s výše uvedenou vyhláškou se zde uvádí úprava organizace výuky, modifikace výukových metod a forem práce, intervence, pomůcky, úpravy obsahu vzdělávání, modifikace hodnocení, příprava na výuku, podpora sociální a zdravotní, práce s třídním kolektivem, úprava prostředí.

\section{Zkušenosti ze školské poradenské praxe v Libereckém kraji}

V praxi školského poradenství s dětmi se zrakovým postižením se nabízí několik otázek, které ale nikde v legislativě přímou oporu nemají. První z nich je orientována na samotného klienta. Kdo je vlastně klientem školského poradenského zařízení? Připravuje-li pracovník ŠPZ pro dítě se zrakovým postižením podporu při vzdělávání ve škole, zpracovává-li Zprávu z vyšetření nebo Doporučení ke vzdělávání, je klientem rozuměno ono dítě. Jeho šetříme, jemu nastavujeme podporu, jeho se týká konzultace se školou. Vyhláška č. 72/2005 přitom ve výčtu standardních činností SPC (společných i se zaměřením na děti se zrakovým postižením) výslovně zmiňuje jako příjemce podpory také pedagogické pracovníky (resp. celou školu) a zákonné zástupce. Terén, zastoupený pedagogickými pracovníky, kteří se podílejí na vzdělávání dítěte se zrakovým postižením, je z našich zkušeností z Libereckého kraje převážně zvyklý považovat za klienta výhradně dítě, eventuálně jeho rodiče, přesněji zákonné zástupce. Spíše výjimečně považují kolegové pedagogičtí pracovníci za klienty také sami sebe. Nemusí být vždy nastaveni na přijetí podpory, mohou ji vnímat jako útok na své kompetence, útok na vlastní, dlouhodobě nastavený a funkční systém vzdělávání dětí ve třídě i mimo ni. Je to ale přirozené a pochopitelné, protože přítomnost jakéhokoliv dítěte se speciálními potřebami ve třídě klade na učitele nároky ve smyslu přehodnocení doposud používaných metod, jejich inovaci, nároky na změny organizace práce, úpravu komunikace a další. 
Další velkou skupinou osob, u kterých je otázkou, zda a do jaké míry jsou klienty ŠPZ, jsou rodinní příslušníci dítěte, nejčastěji rodiče (resp. zákonní zástupci), prarodiče, sourozenci. Zde se nabízejí dvě základní oblasti, ve kterých rodina potřebuje podporu. První z nich je oblast v podstatě technická. Jedná se o poradenství a vedení v oblasti práce s dítětem ve smyslu jeho rozvoje, s ohledem na zrakové postižení. Seznámení s postupy reedukace zraku, kompenzace zraku, rozvoje komunikačních dovedností, seznámení se speciálními pomůckami apod. Druhou oblastí je práce s rodinou ve smyslu zpracování traumatu rodičů vzniklého na základě postižení dítěte, posilování vztahových vazeb v rodině, práce se sourozenci. De facto se tedy jedná o psychoterapii nebo přesněji rodinnou terapii. Ze zkušenosti víme, že v mnoha rodinách jsou nevyřešené vztahové problémy a nepřijetí postižení dítěte překážkou při zcela elementární podpoře (již zmíněná reedukace, kompenzace, práce s pomůckami apod.). Máme za to, že by se proto mělo jednat o samozřejmou součást podpory, pakliže rodina vysloví svůj zájem. Jedině tak je možné efektivně zvyšovat kvalitu života nejenom samotného dítěte se zrakovým postižením, ale celé rodiny jako systému. A také poskytovat efektivně speciálně pedagogickou podporu v jejím původním, technickém slova smyslu. Tento požadavek ovšem může být komplikován skutečností, že pro výkon práce psychologa školského poradenského zařízení není výslovně požadován také psychoterapeutický výcvik, ideálně výcvik v rodinné terapii. Zkušenosti z našeho SPC ukazují na zvyšující se zájem o tuto formu služeb. Přínos vnímáme nejenom u rodin, které vychovávají dítě s těžkým zrakovým postižením, ale i tam, kde je zrakové postižení dítěte klasifikováno jako lehké.

Třetí skupinou, která by v souvislosti s klientelou SPC měla být zmíněna, je intaktní veřejnost. Vycházíme z pojetí J. Slowíka (2007, s. 17), který uvádí, že „Ačkoliv to zatím nebývá př́lišs často otevřeně deklarováno, mezi současné cíle speciální pedagogiky musí jednoznačně patřit také výchova a vzdělávání intaktní (nepostižené) populace ve vztahu k lidem s postižením." Práce s intaktní společnosti ve smyslu zvyšování její informovanosti s cílem odbourávání obav a předsudků považujeme za jeden z nástrojů pro zvyšování kvality života samotných lidí se zrakovým postižením. Na tuto oblast je možné cílit např. zážitkovými semináři pro celé třídy, pro učitelské kolektivy, workshopy apod. S podobnými aktivitami máme výborné zkušenosti.

Doposud jsme se zamýšleli nad tím, kdo je klientem v obecném pojetí. Zajímavá je ale také otázka, kdo je typickým klientem SPC se zrakovým postižením? V tradičním pojetí je to dítě, které má jasnou oftalmologickou diagnózu - tedy má zrakovou vadu, z ní plyne zrakové postižení promítající se do omezené schopnosti nebo neschopnosti vykonávat určité činnosti (nap̌̌. číst a psát černotisk, číst běžnou velikost písma, realizovat samostatný pohyb atd.), z postižení pak často plyne také zrakový handicap, který se již promítá do sociálních rolí a vztahů. Tedy dítě, které má „pouze“ zrakovou vadu. U těchto dětí je možné aplikovat tradiční tyflopedický přístup, který většinou přináší očekávaný efekt. Přináší ho tehdy, pokud pedagog pochopí z našeho pohledu zásadní specifikum velké části dětí se zrakovou vadou, potažmo zrakovým postižením. A totiž, že dítě potřebuje podporu i přesto, že na něm jeho obtíže nemusí být na první pohled patrné (ne všechny zrakové vady se manifestují postřehnutelnými změnami na samotném oku) a že deklaruje, že se mu v hodině pracuje dobře, nemá žádný problém a vše dobře vidí.

Zejména v posledních letech se ovšem musíme vyrovnávat s postupnou proměnou klientely. Poradenství často využívají děti, žáci a studenti, u nichž sice není diagnostikována zraková vada (nebo diagnostikována je, ale zároveň je také dobře kompenzována brýlemi) a které přesto mají obtíže ve zrakové percepci. Dále děti, žáci a studenti, jejichž speciální vzdělávací potřeby plynou nejenom ze zrakové vady, ale zároveň také například z odlišného sociokulturního prostředí, jiných životních podmínek, narušené komunikační schopnosti, poruchy pozornosti s hyperaktivitou a dalších. Zcela samostatnou kapitolou jsou pak děti se zrakovou vadou, u kterých ve škole sledujeme projevy typické pro specifické učení. Toto téma ale zasluhuje samostatné pojednání, proto se mu v rámci tohoto př́íspěvku podrobněji nevěnujeme.

Metodika práce s klientem s kombinací SVP najednou není vůbec tak jednoznačná, jako by byla v případě, že je u dítěte přítomna pouze zraková vada. Nelze tedy pracovat „,bezhlavě“ tyflopedicky, tento přístup zpravidla nepřináší kýžený efekt, často neřeší příčinu obtíží dítěte, dostáváme se do situace, kdy sice všechny technické parametry vzdělávání jsou nastaveny víceméně správně, ale dítě ve škole přesto neprosperuje. Takový přístup pak nevyhnutelně vede k demotivaci všech zúčastněných (včetně poradenského pracovníka) a do popředí se v těchto případech nutně dostává právě multidisciplinární přístup - z našeho pohledu v podstatě jediná možná cesta, jak prosperitu dítěte postupně obnovit, nebo zcela nově nastolit. Multidisciplinární př́istup je možné dle Robertsona (2020) chápat jako práci týmu odborníků, ve kterém 
má každý jinou profesi, jinak stanovené cíle, tým se sice společně schází u jednoho „případu“, ale jednotliví odborníci pracují nezávisle na sobě.

Proto snad ještě lépe, než multidisciplinární přístup, by bylo vhodné jmenovat transdisciplinární přístup v podpoře klienta. Transdisciplinární přístup popisuje Robertson (2020) jako nejvyšší stupeň spolupráce multiprofesionálního týmu. Týmová práce je v tomto př́padě vysoce kolaborativní, hranice mezi rolemi jednotlivých členů týmu se mohou stírat, členové týmu rozšiřují své odborné kompetence za hranice své mateřské disciplíny. Právě tento přístup se v naší praxi nejvíce osvědčuje, ačkoliv jeho aplikace je extrémně náročná. Po poradenských pracovnících vyžaduje vysoce odborný, proaktivní přístup k řešení zakázek jednotlivých klientů, neustálé vzdělávání v oborech a oblastech, které s jeho podporou souvisejí nebo výborné komunikační dovednosti směrem ke členům týmu i ke klientovi a dalším osobám v jeho okolí. V souvislosti s podporou dítěte se zrakovým postižením spatřujeme velký význam v zapojení především ortoptisty, fyzioterapeuta se zaměřením na neurovývojovou stimulaci spolu s řešení přetrvávajících primárních reflexů, a také již zmiňovaného rodinného terapeuta. S těmito odborníky se v rámci možností snažíme spolupracovat, nicméně narážíme v našem regionu na jejich zoufalý nedostatek. Velmi bychom uvítali také pracovníka v oblasti sociální podpory rodiny. Kromě nedostatku pracovníků je komplikací také skutečnost, že školský poradenský systém s těmito profesemi nepočítá, podpůrná opatření jako taková na tyto oblasti a profese nemyslí vůbec. Praktický důsledek je pak ten, že jejich služby nejsou poskytovány bezplatně a navíc jsou obtížněji dostupné (jak z hlediska časového, tak z hlediska prostorového). To je pro řadu klientských rodin, které mají naléhavou potřebu řešit komplexně obtíže svého dítěte, nepřekonatelná bariéra.

\section{Závěr}

Příspěvek nabídl zamyšlení nad současnou podobou poskytování školského poradenství, nad jeho limity a možnostmi s ohledem na proměňující se klientelu. Výstupem je skutečnost, že zásadní vliv na efektivitu celého poradenského procesu má multioborová spolupráce. Ve vztahu k dětem se zrakovým postižením by tak součástí týmu měly být nejenom tradiční profese školského poradenství (speciální pedagog, psycholog, ev. sociální pracovník), ale také ortoptista, fyzioterapeut se zaměření na práci s dětskými klienty/ pacienty a neurovývojovou stimulaci, či odborník s výcvikem v rodinné terapii. To vše s cílem zajistit prosperitu dítěte ve školním i mimoškolním prostředí.

\section{Literatura}

Janková, J. \& kol. (2015). Katalog podpůrných pro žáky s potřebou podpory z důvodu zrakového postižení a oslabení zrakového vnímání. Olomouc: UP. ISBN 978-80-244-4649-3.

Robertson, D. (2020). Multidisciplinary Team: Encyclopedia of Aging. Encyclopedia.com [online]. [cit. 2020-04-23]. Dostupné z: https://www.encyclopedia.com/medicine/anatomy-and-physiology/anatomy-and-physiology/multidisciplinary-team $\$ 3402200275$

Slowík, J. (2007). Speciální pedagogika. Praha: Grada. ISBN 978-80-247-1733-3.

Valenta, M. \&. kol. (2003). Přehled speciální pedagogiky a školské integrace. Olomouc: Univerzita Palackého. ISBN 80-244-0698-5.

Vyhláška č. 72/2007 Sb., o poskytování poradenských služeb ve školách a školských poradenských zařízeních, ve znění účinném od 1.1.2021. (2021). https://www.msmt.cz/dokumenty-3/vyhlasky-ke-skolskemu-zakonu

Vyhláška č. 27/2016 Sb., o vzdělávání žáků se speciálními potřebami a žákủ nadaných, ve znění účinném od 1.1.2021. (2021). https://www.msmt.cz/dokumenty-3/vyhlasky-ke-skolskemu-zakonu

Zákon č. 561/2004 Sb., o předškolním, základním, středním, vyšším odborném a jiném vzdělávání (školskú zákon), ve znění účinném od 27. 2. 2021. (2021). https://www.msmt.cz/dokumenty-3/skolsky-zakon-ve-zneni-ucinnem-ode-dne-27-2-2021 


\section{Informace o autorovi}

\section{Mgr. Hana Ryšlavá, Ph.D.}

Pracuji na Technické univerzitě v Liberci, Fakultě přírodovědně-humanitní a pedagogické, Katedře sociálních studií a speciální pedagogiky. Při práci se studenty se zaměřuji zejména na oblast speciální pedagogiky jedinců se zrakovým postižením, společného vzdělávání a poradenství.

Kromě toho působím jako speciální pedagog také ve Speciálněpedagogickém centru pro zrakově postižené v Liberci.

Možnost ověřovat teoretické poznatky v praxi a zároveň obohacovat výuku studentů o aktuální poznatky z terénu považuji za ideální propojení obou „světů“.

Telefon: +420 485354221

Email: hanka.ryslava@seznam.cz 